\title{
Response of Tuberose (Polianthes tuberosa) to potassium and planting depth
}

\author{
Mohammad Asad Hussain ${ }^{1}$, Noor ul Amin ${ }^{1}$, Abdul Mateen Khattak ${ }^{1}$, \\ Mohammad Ilyas $^{1 *}$, Gulzarullah ${ }^{1}$, Ibrar Hussain ${ }^{2}$, Imran Habib Khan ${ }^{1}$, \\ Fawad Naeem ${ }^{1}$ and Anwar Rashid ${ }^{1}$ \\ 1. Department of Horticulture,The University of Agriculture, Peshawar-Pakistan \\ 2. Agriculture Research Institute Tarnab Peshawar-Pakistan \\ *Corresponding author's email: ilyas_swati88@yahoo.com \\ Citation \\ Mohammad Asad Hussain, Noor ul Amin, Abdul Mateen Khattak, Mohammad Ilyas, Gulzarullah, Ibrar Hussain, \\ Imran Habib Khan, Fawad Naeem and Anwar Rashid. Response of Tuberose (Polianthes tuberosa) to potassium and \\ planting depth. Pure and Applied Biology. Vol. 5, Issue 4, pp1101-1106. \\ http://dx.doi.org/10.19045/bspab.2016.50132
}

Received: $23 / 07 / 2016$

Revised: $27 / 09 / 2016$

Accepted: 06/10/2016

Online First: 18/10/2016

\section{Abstract}

A research work was carried out to find out the effect of planting depths and potassium levels on Tuberose (Polianthes tuberosa). The corms of tuberose were planted at a depth of 5, 10, and 15 $\mathrm{cm}$ and were fertilized with four levels of potassium $0,50,100$ and $150 \mathrm{Kg}$ of K2O ha ${ }^{-1}$ using $\mathrm{K} 2 \mathrm{SO} 4$ as a source of $\mathrm{K} 2 \mathrm{O}$. Result of the study revealed that planting depth of $15 \mathrm{~cm}$ significantly affect days to first and last florets opening and increased length of spike, number of florets spike ${ }^{-1}$, and plant height. Planting depth of $5 \mathrm{~cm}$ causes decreased number of days to last floret opening. Potassium level of $150 \mathrm{~kg}$ of $\mathrm{K} 2 \mathrm{O}$ ha-1increase spike length, number of florets spike $^{-1}$ and plant height. Planting depth of $15 \mathrm{~cm}$ and fertilizer application of $150 \mathrm{~kg}$ of K2O ha1proved to be superior regarding spike length, number of florets and plant height, number of florets spike ${ }^{-1}$ and plant height. Hence planting tuberose at a depth of $15 \mathrm{~cm}$ and fertilizer application of $150 \mathrm{~kg}$ of $\mathrm{K} 2 \mathrm{O} \mathrm{ha} \mathrm{ha}^{-1}$ is recommended for commercial cultivation of tuberose.

Keywords: Tuberose; Potassium; Planting; Depth

Introduction

Tuberose has its place in Amaryllidiaceae family and its origin is Mexico. The major use of tuberose is as cut flower and as it is famous for its sweet fragrance. The extract of tuberose is also used in making perfumes [1]. Their white colored floret has very potential demand in the markets [2]. Tuberose has two main problems regarding its vase life. One is sensitivity of ethylene and the other is vascular tissues blockage [3]. Germicides such as citric acid, cobalt chloride etc. is recommended for enhancing post-harvest life of tuberose [4]. Reproduction through bulbs is the main source of asexual means of propagation [5]. Suitable planting depth for bulbous plants is vital factor in achievement of best quality of flowers [6]. Proper planting depth for tuberose is consider between $3 \mathrm{~cm}$ and $10 \mathrm{~cm}$ but it depends on environmental conditions and type of (medium) soil [7]. Potassium is very important for proper plant growth. It is connection with very vital physiological and bio-chemical processes. It is involved in regulation of stomata during transpiration 
and photosynthesis, enzymes activation and turgor pressure maintenance [8]. Potassium is involved in limiting rotting of bulb underground. Potassium deficiency causes less number of buds, result in short stem of flowers and delaying flowering. Yellowing of older leaves and inter-venal yellowing occur as a result of potassium deficiency [9]. In bulbous plants planting depth has also a significant effect on flowering. For tuberose generally $4-7 \mathrm{~cm}$ planting depth is recommended. Planting depth is dependent on bulb size. Bigger bulbs should be planted deeper in the soil. Similarly bulbs should be planted deeper in the sandy soil as compared to clay soil and a result of deeper planting sprouting is also delayed [10]. Keeping in view the significance of potassium and Planting depth, a research work to realize the influence of these factors on Tuberose was carried out in Horticulture Farm University of Agriculture, Peshawar during the year 2012.

\section{Materials and methods}

Experimental material

The experiment response of tuberose (Polianthes tuberosa cvsingle) to potassium and proper planting depth, was conducted in Horticulture Farm University of Agriculture, Peshawar, Pakistan during the year 2012.

The bulbs of tuberose were planted at different planting depths $(5,10$ and $15 \mathrm{~cm})$ in soil on 28th of February 2012. The field was fertilized with different level of potassium $(0,50100$, and $150 \mathrm{~kg}$ of $\mathrm{K} 2 \mathrm{O}$ $\left.\mathrm{ha}^{-1}\right)$. All the other cultural practices such as weeding, irrigation etc. were uniform throughout the experiment. The experiment was laid out as Randomized Complete Block Design (RCBD) with split plot arrangement. Potassium was kept in Main plot and planting depth was kept in Sub-Plot. There were 3 replications in the experiment. A total of 10 bulbs were planted in each treatment.
Treatments detail

\begin{tabular}{|l|l|}
\hline $\begin{array}{l}\text { Potassium levels kg } \\
\text { ha }^{-1} \text { Factor A }\end{array}$ & $\begin{array}{l}\text { Planting Depths } \\
\text { (cm) Factor B }\end{array}$ \\
\hline 0 & 5 \\
\hline 50 & 10 \\
\hline 100 & 15 \\
\hline 150 & \\
\hline
\end{tabular}

Result and discussion

Days to first floret opening

Planting depth had a significant effect on tuberose regarding number of days to first floret opening. Planting depth of $15 \mathrm{~cm}$ for tuberose corms showed maximum number of days (193.58) to first floret opening and minimum number of days (162.33) to first floret opening were calculated when the corms were planted at depth of $5 \mathrm{cmthis}$ is clearly due to the maximum and minimum distance of growing points to the surface of the earth [7]. There was a significant interaction between planting depth and potassium levels. Control level of potassium took maximum number of days to first floret opening (193.51) and then increased potassium level delayed the days to first floret opening as compared to the low level of potassium. These results are similar to findings of [9], [10] who stated that increase in potassium dose delay flowering in bulbous flowers. According to [11] there is a remarkable effect of planting depth in flower bulbs regarding days to sprouting.

\section{Spike length at first floret opening (cm)}

Potassium showed significant effect on the spike length at first floret opening. Potassium at the rate of $150 \mathrm{~kg} \mathrm{~K} 20$ gave maximum length of $40.133 \mathrm{~cm}$ at first floret opening and minimum length was recorded as $33.622 \mathrm{~cm}$ in the potassium level of 50 $\mathrm{Kg}$ of $\mathrm{K}_{2} \mathrm{O} \mathrm{ha}^{-1}$.Maximum length of 44.017 $\mathrm{cm}$ was shown by planting depth of $15 \mathrm{~cm}$ at first floret opening while the minimum value of the same parameter was $28.617 \mathrm{~cm}$ by $5 \mathrm{~cm}$ planting depth. Significant interaction was observed between potassium and planting depth. Maximum length was noted 
$46.73 \mathrm{~cm}$ by the effect of $150 \mathrm{~kg}$ of $\mathrm{K}_{2} \mathrm{O}$ ha ${ }^{1}$ and $15 \mathrm{~cm}$ planting depth while on the other hand minimum length of $28.267 \mathrm{~cm}$ was recorded by the control level of $\mathrm{K}$ and planting depth of $5 \mathrm{~cm}$.Spike length is increased by increasing the level of Potassium. Potassium at the rate of $150 \mathrm{~kg}$ of $\mathrm{K}_{2} \mathrm{O}$ ha $^{-1}$ gave the maximum height (40.13 $\mathrm{cm})$ due to more $\mathrm{K}$ availability. The Potassium increases the flower stem height [9]. These results are in conformity with those of [10] who observed that increasing potassium increased plant height in dahlia. Planting depth of $15 \mathrm{~cm}$ resulted in superior spike length (44.02) deeper planting gives the best length for spike for as confirmed by the findings of [12] for freesia.

\section{Days to last floret opening}

The application of potassium significantly affected days to last floret opening. In the absence of potassium it took maximum number of days to open the last florets (209.89). On the other hand when $50 \mathrm{~kg}$ of $\mathrm{K}_{2} \mathrm{O} / \mathrm{ha}^{-1}$ was applied it took minimum number of 189.02 days to open last florets. These results are similar to the findings of $[9,10]$. According to them increase in potassium dose delay flowering in bulbous flowers. Bulbs planted at $15 \mathrm{~cm}$ planting depth took maximum number of days (211.70) to last floret opening and last floret opened earlier after 189.02 days when bulbs planted $5 \mathrm{~cm}$ deep. Bulbs planted at shallow depth sprouts earlier and as a result their floret also open earlier [7]. Interaction between planting depth and potassium was also significant. Combination of $15 \mathrm{~cm}$ planting depth and potassium level of 100 $\mathrm{kg}$ of $\mathrm{K}_{2} \mathrm{Oha}^{-1} 216.53$ days to last floret opening and minimum number of 166.67 days were taken by the combination of $5 \mathrm{~cm}$ planting depth and $150 \mathrm{~kg}$ of $\mathrm{K}_{2} \mathrm{Oha}^{-1}$.

Table 2.Response of days to first floret opening, spike length $(\mathrm{cm})$ at first floret opening and days to last floret opening, of tuberose (Polianthes tuberosa) to potassium and planting depth

\begin{tabular}{|c|c|c|c|}
\hline Treatments & $\begin{array}{l}\text { Days to First Floret } \\
\text { Opening }\end{array}$ & $\begin{array}{l}\text { Spike length }(\mathrm{cm}) \text { at } \\
\text { first floret Opening }\end{array}$ & $\begin{array}{l}\text { Days to Last Floret } \\
\text { Opening }\end{array}$ \\
\hline K1 & $193.51 \mathrm{a}$ & $37.04 \mathrm{~b}$ & $209.89 \mathrm{a}$ \\
\hline $\mathrm{K} 2$ & $168.62 \mathrm{c}$ & $33.62 \mathrm{c}$ & $189.02 \mathrm{~b}$ \\
\hline K3 & $175.58 \mathrm{bc}$ & $34.97 \mathrm{c}$ & $192.59 \mathrm{~b}$ \\
\hline K4 & $179.37 \mathrm{~b}$ & $40.13 a$ & $194.33 b$ \\
\hline LSD $(P \leq 0.05)$ & 7.27 & 1.91 & 6.18 \\
\hline $\mathrm{P} 1$ & $162.33 c$ & $28.61 \mathrm{c}$ & $180.08 \mathrm{c}$ \\
\hline $\mathrm{P} 2$ & $181.89 \mathrm{~b}$ & $36.7 \mathrm{~b}$ & $197.59 \mathrm{~b}$ \\
\hline $\mathrm{P} 3$ & $193.58 \mathrm{a}$ & $44.02 \mathrm{a}$ & $211.70 \mathrm{a}$ \\
\hline LSD $(P \leq 0.05)$ & 8.70 & 2.68 & 9.13 \\
\hline $\mathrm{K} 1 \times \mathrm{P} 1$ & 190.53 & 28.26 & 201.27 \\
\hline $\mathrm{K} 1 \times \mathrm{P} 2$ & 196.60 & 41.73 & 215.13 \\
\hline $\mathrm{K} 1 \times \mathrm{P} 3$ & 193.40 & 41.13 & 213.27 \\
\hline $\mathrm{K} 2 \times \mathrm{P} 1$ & 145.80 & 25.13 & 179.80 \\
\hline $\mathrm{K} 2 \times \mathrm{P} 2$ & 172.53 & 32.73 & 185.27 \\
\hline $\mathrm{K} 2 \times \mathrm{P} 3$ & 187.53 & 43.0 & 202.00 \\
\hline $\mathrm{K} 3 \times \mathrm{P} 1$ & 156.73 & 28.93 & 172.60 \\
\hline $\mathrm{K} 3 \times \mathrm{P} 2$ & 172.53 & 30.8 & 188.63 \\
\hline $\mathrm{K} 3 \times \mathrm{P} 3$ & 197.07 & 45.2 & 216.53 \\
\hline $\mathrm{K} 4 \times \mathrm{P} 1$ & 156.27 & 32.13 & 166.67 \\
\hline $\mathrm{K} 4 \times \mathrm{P} 2$ & 185.50 & 41.53 & 201.33 \\
\hline $\mathrm{K} 4 \times \mathrm{P} 3$ & 196.33 & 46.73 & 215.00 \\
\hline LSD $(P \leq 0.05)$ & 15.94 & 4.78 & 15.94 \\
\hline
\end{tabular}




\section{Spike length at last floret opening}

The data regarding spike length at last floret opening shows the maximum length of spike $56.96 \mathrm{~cm}$ was obtained when the corms were planted at $15 \mathrm{~cm}$ planting depth and on the other hand minimum length of $39.36 \mathrm{~cm}$ was observed at the depth of $5 \mathrm{~cm}$ planting depth. The deeper planted showed maximum length of spike because of maximum availability of water in the deeper zone of soil. As water act as a solvent for nutrients so a result maximum length is obtained. Potassium also significantly improved the spike length at last floret opening stage. Maximum length of $55.24 \mathrm{~cm}$ was obtained when potassium was applied at the rate of $150 \mathrm{~kg} \mathrm{ha}^{-1} \mathrm{~K}_{2} \mathrm{O}$, while on the other side minimum length of $44.88 \mathrm{~cm}$ was achieved as a result of $50 \mathrm{~kg} \mathrm{ha}^{-1} \mathrm{~K}_{2} \mathrm{O}$. Potassium is the main nutrient for plant growth, its deficiency cause many abnormalities in the plant including weak root system, stunted growth of stem and yellowing of leaves [9]. Thus Potassium is the main reason for good quality growth. The two factors planting depth and potassium also significantly interacted with each other. Planting tuberose bulbs at $15 \mathrm{~cm}$ and potassium application of $150 \mathrm{~kg} \mathrm{ha}^{-1} \mathrm{~K}_{2} \mathrm{O}$ gives the superior length of spike of $64.4 \mathrm{~cm}$.

Number of florets spike ${ }^{-1}$

Planting depth has a significant effect on number of florets per spike. Maximum numbers of florets i.e. 54.83 were produced when the bulbs were planted $15 \mathrm{~cm}$ deep in the soil. On the other hand potassium application of $150 \mathrm{~kg} \mathrm{ha} \mathrm{h}^{-1}$ resulted in maximum number of florets per spike (49.2). The interaction of planting depths and potassium levels was also significant. Maximum number of florets per spike (62.2) was observed when the corms were planted $15 \mathrm{~cm}$ deep in the soil and treated with 150 $\mathrm{kg} \mathrm{K}_{2} \mathrm{O}$ ha $^{-1}$. While on the other hand minimum number of florets per spike (34.0) were obtained as result of interaction of $5 \mathrm{~cm}$ planting depth and control level of potassium. Increasing potassium level increases the florets per spike. $150 \mathrm{~kg} \mathrm{~K}_{2} \mathrm{O}$ $\mathrm{ha}^{-1}$ gave the maximum number of florets per spike (40.13). Potassium is involved in formation of chlorophyll as stated by Carroll and $[9,10]$ quoted that increased number of florets per spike is the result of manufacturing of amino acids, chlorophyll synthesis and swift carbohydrates conversion, which outcome as better growth and maximum number of florets. These results are alike with [10].

\section{Plant height}

Plant height is significantly affected by planting depth. Maximum height of 103.13 $\mathrm{cm}$ is obtained when the corms were planted $15 \mathrm{~cm}$ deep in the soil while on the other hand $88.3 \mathrm{~cm}$ plant height was obtained when planting corms $5 \mathrm{~cm}$ deep in the soil. Deeper planting results in maximum length of spike. These results are confirmed by [12] for freesia, and [13] for tuberose. Maximum plant height $100.29 \mathrm{~cm}$ was obtained when corms were treated with $150 \mathrm{~kg}$ of $\mathrm{K}_{2} \mathrm{O} \mathrm{ha}^{-1}$. Maximum plant height is the outcome of better food intake as result of strong root system caused by optimum potassium present in soil. Interaction of planting depth and potassium also turns out to be significant. Treatment of $150 \mathrm{~kg}$ of $\mathrm{K}_{2} \mathrm{O} \mathrm{ha}^{-1}$ gives the maximum plant height of $106.2 \mathrm{~cm}$ when the bulbs were planted at 10 and 15 $\mathrm{cm}$. It is confirmed from the data above the planting Tuberose bulbs at a depth of $15 \mathrm{~cm}$ results in the enhancing of Tuberose floral characteristics like spike length, number of florets per spike and final plant height. On the other hand potassium also significantly increased number of florets per spike and Plant height. Thus it is recommended to plant tuberose bulbs at a depth of $15 \mathrm{~cm}$ and potassium $\left(\mathrm{K}_{2} \mathrm{O}\right)$ application at the rate of $150 \mathrm{Kg}$ of $\mathrm{K}_{2} \mathrm{O} \mathrm{ha}^{-1}$ for the agro-ecological conditions of Peshawar, Pakistan. 
Table 3.Response of spike length $(\mathrm{cm})$ at last floret opening, number of florets spike ${ }^{-1}$ and plant height $(\mathrm{cm})$ of tuberose (Polianthes tuberosa) to potassium and planting depth

\begin{tabular}{|c|c|c|c|}
\hline Treatments & $\begin{array}{l}\text { Spike length }(\mathrm{cm}) \text { at last } \\
\text { floret opening }\end{array}$ & $\begin{array}{l}\text { Number of Florets } \\
\text { Spike }^{-1}\end{array}$ & Plant Height $(\mathrm{cm})$ \\
\hline K1 & $37.04 \mathrm{~b}$ & $47.2 \mathrm{ab}$ & $97.87 \mathrm{ab}$ \\
\hline K2 & $33.62 \mathrm{c}$ & $43.8 b$ & $93.49 \mathrm{c}$ \\
\hline K3 & $34.97 \mathrm{c}$ & $43.73 b$ & $95.56 \mathrm{bc}$ \\
\hline K4 & $40.13 a$ & $49.2 \mathrm{a}$ & $100.29 a$ \\
\hline LSD $(P \leq 0.05)$ & 1.91 & 4.01 & 1.72 \\
\hline $\mathrm{P} 1$ & $28.61 \mathrm{c}$ & $35.7 \mathrm{c}$ & $88.30 \mathrm{c}$ \\
\hline $\mathrm{P} 2$ & $36.7 b$ & $47.41 \mathrm{~b}$ & $98.97 \mathrm{~b}$ \\
\hline $\mathrm{P} 3$ & $44.02 \mathrm{a}$ & $54.83 a$ & $103.13 \mathrm{a}$ \\
\hline LSD $(P \leq 0.05)$ & 2.68 & 3.47 & 1.78 \\
\hline $\mathrm{K} 1 \times \mathrm{P} 1$ & 28.26 & 34.0 & 186.47 \\
\hline $\mathrm{K} 1 \times \mathrm{P} 2$ & 41.73 & 49.4 & 102.47 \\
\hline $\mathrm{K} 1 \times \mathrm{P} 3$ & 41.13 & 58.2 & 104.67 \\
\hline $\mathrm{K} 2 \times \mathrm{P} 1$ & 25.13 & 35.86 & 87.60 \\
\hline $\mathrm{K} 2 \times \mathrm{P} 2$ & 32.73 & 48.26 & 92.73 \\
\hline $\mathrm{K} 2 \times \mathrm{P} 3$ & 43.0 & 47.26 & 100.13 \\
\hline $\mathrm{K} 3 \times \mathrm{P} 1$ & 28.93 & 38.86 & 90.67 \\
\hline $\mathrm{K} 3 \times \mathrm{P} 2$ & 30.8 & 40.66 & 94.47 \\
\hline $\mathrm{K} 3 \times \mathrm{P} 3$ & 45.2 & 51.33 & 101.53 \\
\hline $\mathrm{K} 4 \times \mathrm{P} 1$ & 32.13 & 34.06 & 818.47 \\
\hline $\mathrm{K} 4 \times \mathrm{P} 2$ & 41.53 & 51.33 & 106.20 \\
\hline $\mathrm{K} 4 \times \mathrm{P} 3$ & 46.73 & 62.2 & 106.20 \\
\hline LSD $(P \leq 0.05)$ & 4.78 & 7.37 & 3.38 \\
\hline
\end{tabular}

\section{Conclusion}

It is concluded from the above experiment that planting tuberose bulbs at the depth of $15 \mathrm{~cm}$ and potassium dose of $150 \mathrm{Kg}$ of $\mathrm{K}_{2} \mathrm{O}$ $\mathrm{ha}^{-1}$ gave excellent results in agro-ecological conditions of Peshawar, Pakistan. So using such practices yield of tuberose can be achieved to its maximum potential.

\section{Authors' contributions}

Conceived and designed the experiments: NU Amin \& AM Khattak, Performed the experiments: MA Hussain, Analyzed the data: GI Hussain, Contributed reagents/ materials/ analysis tools: F Naeem \& A Rashid, Wrote the paper: M Ilyas \& IH Khan.

\section{References}

1. Biswas J, Bose JK \& Matti RG (1983). Effect of growth substances on growth and lowering of tuberose (Polianthes tuberosa L.). South Indian Hort 31(2/3): 129-132.

2. Dahiya SS, Mohansundram S, Sukhbir, Singh, Dahiya DS \& Singh S (2001). Effect of nitrogen and phosphorus on growth and dry matter yield of tuberose (Polianthes tuberosa L.). Haryana J. Hort. Sci 30(3/4): 198-200.

3. Edrisi B \& Payam-e D (2009). Effect of nitrogen and Plant Spacing on Nutrients uptake, yield and growth of Tuberose (Polianthes tuberose L.) $150 \mathrm{p}$.

4. Damunpula JW, Joyce DC \& Jpan J (2006). Hort. Sci 77: 1-18

5. Mahanta P \& Paswan L (1999). Effect of bulb size and spacing on growth, flowering and bulb production of tuberose (Polianthes tuberosa L.) cv. 
Single. Horticultural Science 8(1): 7583.

6. Hagiladi A, Umiel N, Ozeri Y, Elyasi R, Abramsky S, Levy A, Lobosky O \& Matan E (1992). The effect of planting depth on emergence and development of some geophytic plants. Acta Horticulture 325: 131-137.

7. Hertogh DA \& Nard ML (1998). The T.K.Bose, 1987. Effect of bulb size, temperature physiology of flower bulbs. Elsevier 177: 183-187.

8. Pettigrew WT (2008). Potassium influences on yield and quality production for maize, wheat, soybean and cotton, physiol. Plant 133: 670681.

9. Wilfret GJ (1980). Gladiolus. In "Introduction to floriculture" (Larson R. A. Ed.). pp. 165-181. Academic Press, Inc. New York.

10. Zubair M, Ayub G, Wazir FK, Khan M \& Mahmood Z (2006). Effect of potassium on pre flowering growth of gladiolus cultivars. Journal of
Agriculture and Biological Science 1(3).

11. Chandy KT (1994). Tuberose Booklet No 405. Flower Gardening: FGS - 35

12. Choi ST, Jung WY, Ahn HG \& Chang YD (1999). Effect of duration of cold treatment and planting depth on growth and flowering of Lilium spp. Korean Society of Horticulture Science 39(6): 765-770.

13. Choi ST, Park IH \& Ahn HG (1997). Effect of planting depth and existence of tunic on growth and flowering in freesia forcing. Korean Society of Horticultural Science 37(4): 577-581

14. Mane PK, Bankar GJ \& Makne SS (2007). Influence of spacing, bulb size and depth of plantingon flower yield and quality of tuberose (Polianthes tuberosa L.) cv. 'single'. Indian journal of Agriculture Research 41(1): 71 - 74 